\title{
Herpetofauna and habitat characteristics of 16 lagoons along the eastern coastline of South Korea
}

\author{
Jung-Hyun Lee ${ }^{1}$, Daesik Park ${ }^{2}$, Heon-Joo Lee ${ }^{1}$, Ja-Kyeong Kim ${ }^{1}$ and Nam-Yong Ra ${ }^{1, *}$ \\ ${ }^{1}$ Department of Biology, Kangwon National University, Chuncheon 200-701, Korea \\ ${ }^{2}$ Division of Science Education, Kangwon National University, Chuncheon 200-701, Korea
}

\begin{abstract}
We conducted field surveys of amphibians and reptiles over a two-year period in 16 lagoons along the eastern coastline of South Korea, and determined the habitat characteristics correlated with the number of amphibian and reptilian species and individuals. We documented 11 amphibian species and 8 reptilian species. The dominant amphibian species was the black-spotted pond frog (Rana nigromaculata), and the dominant reptilian species was the red-eared turtle (Trachemys scripta elegans), an invasive species. Among the 14 habitat characteristics, connectivity to mountainous area significantly affected the number of amphibian and reptilian individuals. Other factors, including emerged plant cover, salinity, $\mathrm{pH}$, the number of birds for amphibians and connectivity to agricultural land, lagoon perimeter length for reptiles also influenced the number of species or individuals of them. Our results demonstrate that these lagoons are home to more amphibians and reptiles than has been previously known. To effectively conserve herpetofauna in the lagoon ecosystem, lagoons as well as surrounding wetlands, grasslands, and mountainous areas should be protected.
\end{abstract}

Key words: amphibian, habitat characteristics, herpetofauna, invasive species, lagoon, reptile

\section{INTRODUCTION}

Lagoons are a type of coastal wetland formed by the combined action of rivers or streams and the ocean (Heo et al. 1999, Hwang and Yoon 2008). Lagoons perform a crucial function in local ecosystems, as both brackish lakes and natural wetlands (Um 1998). In South Korea, 18 lagoons were reported along the eastern coastline in Gangwon-do: seven lagoons in Koseong-gun (Hwajinpoho, Seonyudam, Songjiho, Cheonjinho, Bongpoho, Bongpo-wetland, Gwangpoho), two lagoons in Sokchosi (Yeongrangho, Cheongchoho), five lagoons in Yangyang-gun (Gapyeongri-wetland, Ssangho, Gungaeho, Yeomgaeho, Maeho), and four lagoons in Gangneung-si (Hyangho, Sunpogaeho, Gyeongpoho, Poongho) (Heo 2009). These lagoons have been disrupted by human activities such as the expansion of agricultural areas, partial modification into recreational parks, and sewage dumping, as well as by natural processes including the accumulation of organic materials and deposits. These lagoons have lost their original topographic shapes and ecological functions in local ecosystems (Um 1998, Kim et al. 2001).

In order to successfully preserve or restore the health of lagoon ecosystems, it is first necessary to understand the local organisms and their habitat requirements (Pough et al. 2004). Recent studies have demonstrated that the systematic connections between wetlands and nearby small wetlands, grasslands, and terrestrial areas are critical for healthy wetland ecosystems (Semlitsch and Bodie 2003). Amphibians and reptiles utilize water bodies and terrestrial areas throughout their lives, and play a key role in (c) This is an Open Access article distributed under the terms of the Creative Commons Attribution Non-Commercial License (http://creativecommons.org/licenses/by-nc/3.0/) which permits unrestricted non-commercial use, distribution, and reproduction in any medium, provided the original work is properly cited.
Received 29 March 2010, Accepted 1 May 2010

${ }^{*}$ Corresponding Author

E-mail: nabre4@naver.com

Tel: +82-33-250-6739 
linking aquatic and terrestrial ecosystems. In South Korea, studies of lagoon ecosystems have been conducted primarily for relatively large lagoons such as Yeongrangho, Cheongchoho, and Gyeongpoho (Heo et al. 1999), and the majority of studies have focused on water quality, plankton populations, and species lists of birds and fishes (Yang 2003). To date, very few studies concerning the herpetofauna of Korean lagoon ecosystems have been conducted (Kim 1997, Shim 2001, Lee and Song 2002a, 2002b). In this study, we identified the amphibian and reptilian species occurring in 16 lagoons along the eastern coastline of South Korea over two years of field surveys, and we investigated the habitat characteristics that affected the number of amphibian and reptilian species as well as the number of individuals of them in these lagoon ecosystems.

\section{MATERIALS AND METHODS}

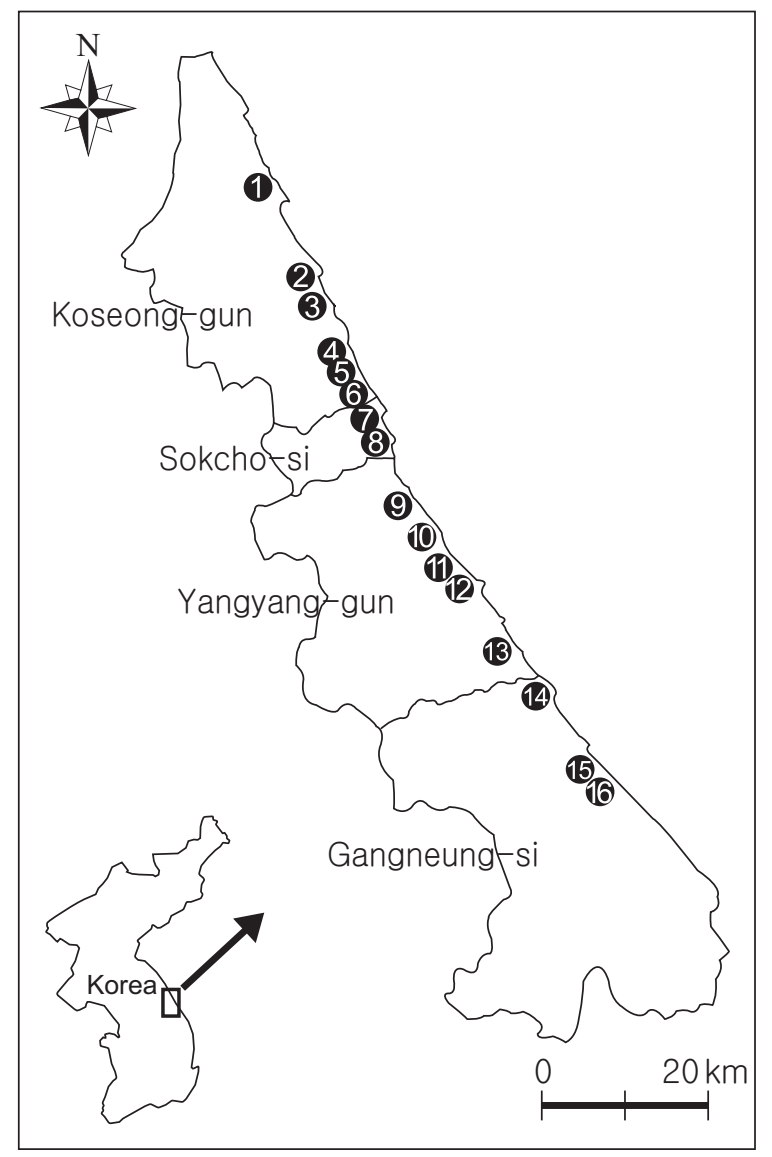

Fig. 1. Locations of 16 lagoons investigated along the eastern coastline of South Korea: (1) Hwajinpoho, (2) Seonyudam, (3) Songjiho, (4) Cheonjinho, (5) Bongpoho, (6) Gwangpoho, (7) Yeongrangho, (8) Cheongchoho, (9) Gapyeongri-wetland, (10) Ssangho, (11) Gungaeho, (12) Yeomgaeho, (13) Maeho, (14) Hyangho, (15) Sunpogaeho, and (16) Gyeongpoho.

\section{Study sites}

We surveyed the herpetofauna and habitat characteristics of 16 lagoons, four times per year in 2007 (29-30 Mar, 29-31 May, 3-4 Jul, 13-14 Sep) and 2008 (18-19 Apr, 15-16 May, 17-19 Jul, 18-19 Sep) (Fig. 1). We excluded two eastern coastline lagoons (Bongpo-wetland and Poongho) from the study, due to the lack of any water bodies for anthropogenic disruptions. Prior to conducting the field surveys, we arbitrarily classified the 16 lagoons into three size groups on the basis of the maximum diameter of each lagoon (derived from a 1:25,000-scale map: $\leq 0.2$ $\mathrm{km}$, between 0.21 and $1.0 \mathrm{~km}$, and $\geq 1.1 \mathrm{~km}$ ). For the lagoons in each group, we designated two (Cheongchoho, Seonyudam, Cheonjinho, Ssangho, Yeomgaeho, Sunpogaeho), three (Gwangpoho, Maeho, Bongpoho, Gungaeho), or five (Hwajinpoho, Songjiho, Yeongrangho, Hyangho, Gyeongpoho) detailed survey sites, respectively. Each survey site was composed of appropriate habitats such as small wetlands, paddy fields, ponds, or streams (for amphibians), and agricultural land or mountains (for reptiles) located within 30-50 m of the lagoon edge.

\section{Field survey}

Two persons with more than four years of experience in field surveys of amphibians and reptiles surveyed each detailed survey site while walking slowly along the boundary of a lagoon for 15 minutes (about $300 \mathrm{~m} \times 20$ $\mathrm{m})$. Upon encountering any amphibians or reptiles, we immediately identified and classified the animals based on the criteria established by Park et al. (2006), Song (2007), and Kim (2009), and recorded the classification in our field notes. Using a stopwatch, we excluded the time required to record the data from the 15-min survey time. We also surveyed juveniles of amphibians at each survey site using a deep net $(0.8 \mathrm{~m}$ length $\times 0.6 \mathrm{~m}$ wide, $5 \mathrm{~mm}$ mesh) for three trials.

To determine the characteristics of amphibian and reptile habitats in lagoons, we measured 14 factors at each detailed survey site: $\mathrm{pH}$; dissolved oxygen (DO); cover indices of submerged plant and emerged plant; number of birds; number of insect orders; distances from the lagoon edge to the nearest road, residential area, and mountain; connectivity to agricultural land and mountainous area; salinity; lagoon size; and lagoon perimeter length. We measured $\mathrm{pH}$ and $\mathrm{DO}$ from $200 \mathrm{~mL}$ of water collected from $1 \mathrm{~m}$ inside the lagoon edge, using a $\mathrm{pH}$ meter (EcoScan; Eutech, Ayer Rajah Crescent, Singapore) and a DO meter (DO-5Z; KRK, Kuki, Japan). The cover 
indices of submerged plant and emerged plant were estimated by two people on a scale of one to five: $0 \%$, $1-25 \%, 26-50 \%, 51-75 \%$, and $76-100 \%$. To determine the number of birds, we only counted large birds belonging to the families Phalacrocoracidae, Ardeidae, and Anatidae, which were either inside the lagoons or within $30 \mathrm{~m}$ of the lagoon edge. To determine the number of insect orders, we captured insects at each survey site using an insect net $(0.5 \mathrm{~mm}$ mesh), five times at each location. The captured insects were then transported to the laboratory in cooling box $\left(<10^{\circ} \mathrm{C}\right)$ and frozen at $-20^{\circ} \mathrm{C}$. The insects were classified up to the order level based on the criteria established by Kim (2005). The cover indices of both submerged plant and emerged plant, number of birds, and number of insect orders were measured exclusively in 2007. The distances from the lagoon edge to the nearest road, residential area, and mountain were estimated using aerial photographs (Daum map sky view 2009). We defined a road as any paved roadway with two or more lanes, and defined a residential area as an area containing more than five houses. The mountain was composed of shrubs and trees. Connectivity to agricultural land and mountainous area was estimated using aerial photographs on an index (1-5 points): $0 \%, 1-25 \%, 26-50 \%, 51-$ $75 \%$, and $76-100 \%$. The data for salinity, lagoon size, and lagoon perimeter length were extracted from the data reported by Heo (2009).

\section{Data analysis}

The number of amphibian and reptilian species was determined as the sum of the species observed at least once during the surveys. To calculate the standardized number of amphibian individuals, we considered each adult, egg mass, tadpole, and single egg as 1, 1, 0.1, and 0.01 individuals, respectively, based on the previous report of Wells (2007). For the reptile individuals, each adult and juvenile was considered as one individual. To compare the number of amphibian and reptilian species and the number of individuals of them with the characteristics of their habitats, we first standardized our data among the lagoons. The calculated number of amphibian and reptilian species and the number of individuals of them at each lagoon were divided by two (two years of surveys), and again by the number of survey sites located in each lagoon. This was also done for the number of birds and insect orders in each lagoon. The pH, DO, and cover indices of submerged plant and emerged plant were averaged across the survey sites in each lagoon. As the majority of the data did not pass the normality test
(Kolmogorov-Smirnov, $P<0.05$ ), relationships between the number of amphibian and reptilian species and the number of individuals of them and their habitat characteristics were analyzed via Spearman's correlations (SPSS ver. 16; SPSS Inc., Chicago, IL, USA).

\section{RESULTS}

\section{Herpetofauna in the lagoons}

A total of 11 amphibian species in 6 genera, 6 families, and 2 orders, as well as 8 reptile species in 7 genera, 4 families, and 2 orders were detected in the surveys (Table 1). Hwajinpoho harbored the greatest number of amphibian and reptilian species, whereas Cheongchoho, Gapyeongri-wetland, and Yeomgaeho harbored the fewest (Table 2). No reptiles were detected in Gwangpoho, Cheongchoho, and Gapyeongri-wetland.

The dominant amphibian species was the black-spotted pond frog, Rana nigromaculata, which was detected in all lagoons (Table 2). The subdominant amphibian species was the American bullfrog, Rana catesbeiana, an invasive species that was found in four lagoons: Cheonjinho, Bongpoho, Gwangpoho, and Yeongrangho. The dominant reptile species was the red-eared turtle, Trachemys scripta elegans, an invasive species which was detected in five lagoons: Hwajinpoho, Songjiho, Yeongrangho, Hyangho, and Gyeongpoho. The subdominant reptile species was the water snake, Elaphe rufodorsata, which was found in 10 lagoons. T. scripta elegans was observed principally within the lagoons, whereas E. rufodorsata was often detected in paddy fields and small wetlands along the shore. The narrow-mouthed toad, Kaloula borealis, and the three-keeled pond turtle, Chinemys reevesii, both of which are designated as endangered category II species in South Korea, were detected in Seonyudam and Hwajinpoho, respectively.

\section{Relationships between the number of amphib- ian and reptilian species and the number of indi- viduals of them and their habitat characteristics}

The number of amphibian species was correlated positively with the cover index of emerged plant $(r=0.567, P$ $=0.022$ ) (Fig. 2a) but was negatively correlated with the number of birds $(r=-0.519, P=0.039)$, salinity $(r=-0.582$, $P=0.018)$, and lagoon size $(r=-0.559, P=0.024)$. The number of amphibian individuals was correlated positively with connectivity to mountainous area $(r=0.537, P$ 
Table 1. The amphibian and reptilian species confirmed in 16 lagoons during surveys in 2007-2008

\begin{tabular}{|c|c|c|c|c|c|c|c|}
\hline \multirow{2}{*}{ Class } & \multirow{2}{*}{ Order } & \multirow{2}{*}{ Family } & \multirow{2}{*}{ Genus } & \multirow{2}{*}{ Species } & \multicolumn{3}{|c|}{ Stage } \\
\hline & & & & & Adult & Larva & Egg \\
\hline \multirow[t]{11}{*}{ Amphibia } & \multirow{11}{*}{$\begin{array}{l}\text { Caudata } \\
\text { Anura }\end{array}$} & Hynobiidae & Hynobius & Hynobius leechii & 1 & 28 & 170 \\
\hline & & Bombinatoridae & Bombina & Bombina orientalis & 69 & 0 & 0 \\
\hline & & \multirow[t]{2}{*}{ Bufonidae } & \multirow[t]{2}{*}{ Bufo } & Bufo gargarizans & 1 & 0 & 3 \\
\hline & & & & Bufo stejnegeri & 1 & 0 & 0 \\
\hline & & Hylidae & Hyla & Hyla japonica & 179 & 296 & 25 \\
\hline & & Microhylidae & Kaloula & Kaloula borealis & 1 & 0 & 0 \\
\hline & & \multirow[t]{5}{*}{ Ranidae } & \multirow[t]{5}{*}{ Rana } & Rana dybowskii & 6 & 304 & 13 \\
\hline & & & & Rana coreana & 211 & 607 & 352 \\
\hline & & & & Rana nigromaculata & 2,462 & 779 & 132 \\
\hline & & & & Rana rugosa & 48 & 369 & 3 \\
\hline & & & & Rana catesbeiana & 679 & 412 & 1 \\
\hline 1 & 2 & 6 & 6 & 11 & 3,658 & 2,795 & 699 \\
\hline \multirow[t]{8}{*}{ Reptilia } & \multirow[t]{2}{*}{ Testudinata } & \multirow[t]{2}{*}{ Emydidae } & Chinemys & Chinemys reevesii & 1 & & \\
\hline & & & Trachemys & Trachemys scripta elegans & 45 & & \\
\hline & \multirow[t]{6}{*}{ Squamata } & Lacertilidae & Takydromus & Takydromus amurensis & 2 & & \\
\hline & & \multirow[t]{4}{*}{ Colubridae } & \multirow[t]{2}{*}{ Elaphe } & Elaphe rufodorsata & 31 & & \\
\hline & & & & Elaphe dione & $10\left(1^{*}\right)$ & & \\
\hline & & & Rhabdophis & Rhabdophis tigrinus tigrinus & 17 & & \\
\hline & & & Dinodon & Dinodon rufozonatum rufozonatum & $\left(2^{*}\right)$ & & \\
\hline & & Viperidae & Gloydius & Gloydius brevicaudus & 3 & & \\
\hline 1 & 2 & 4 & 7 & 8 & $109\left(3^{*}\right)$ & & \\
\hline
\end{tabular}

*Roadkill.

Table 2. Amphibians and reptiles confirmed in each lagoon during the 2007-2008 surveys

\begin{tabular}{|c|c|c|c|c|c|c|c|c|c|c|c|c|c|c|c|c|c|}
\hline Order & Species & $\begin{array}{l}\text { Hwajin- } \\
\text { poho }\end{array}$ & $\begin{array}{l}\text { Seonyu- } \\
\text { dam }\end{array}$ & Songjiho & $\begin{array}{l}\text { Cheon- } \\
\text { jinho }\end{array}$ & $\begin{array}{l}\text { Bong- } \\
\text { poho }\end{array}$ & $\begin{array}{l}\text { Gwang- } \\
\text { poho }\end{array}$ & $\begin{array}{l}\text { Yeon- } \\
\text { grangho }\end{array}$ & $\begin{array}{l}\text { Cheon- } \\
\text { gchoho }\end{array}$ & $\begin{array}{l}\text { Gapy- } \\
\text { eongri- } \\
\text { wetland }\end{array}$ & Ssangho & $\begin{array}{l}\text { Gun- } \\
\text { gaeho }\end{array}$ & $\begin{array}{c}\text { Yeomgae- } \\
\text { ho }\end{array}$ & Maeho & Hyangho & $\begin{array}{l}\text { Sunpo- } \\
\text { gaeho }\end{array}$ & $\begin{array}{c}\text { Gyeong- } \\
\text { poho }\end{array}$ \\
\hline Caudata & Hynobius leechii & & (9) & (8) & & & & & & & & & & (32) & 134 & & (16) \\
\hline \multirow[t]{10}{*}{ Anura } & $\begin{array}{l}\text { Bombina } \\
\text { orientalis }\end{array}$ & & 69 & & & & & & & & & & & & & & \\
\hline & Bufo gargarizans & (3) & & & & & & & & & & & & & & 1 & \\
\hline & Bufo stejnegeri & & & & & & & & & & & & & & & 1 & \\
\hline & Hyla japonica & 315 & 80 & 21 & 7 & 2 & 2 & 15 & 2 & 2 & 10 & 15 & & 8 & 5 & 2 & 14 \\
\hline & Kaloula borealis & & 1 & & & & & & & & & & & & & & \\
\hline & Rana dybowskii & 204 & 100 & 11 & & & 2 & 1 & & & & & & 4 & 1 & & \\
\hline & Rana coreana & 294 & (1) & 244 & & 7 & 210 & 155 & & & 18 & 18 & & 61 & 85 & 24 & 53 \\
\hline & $\begin{array}{l}\text { Rana } \\
\text { nigromaculata }\end{array}$ & 748 & 400 & 709 & 9 & 130 & 265 & 206 & 4 & 32 & 101 & 146 & 120 & 63 & 157 & 166 & 117 \\
\hline & Rana rugosa & 64 & 8 & 95 & & & & 5 & & & 108 & 139 & & & & 1 & \\
\hline & Rana catesbeiana & & & & 504 & 533 & 50 & 5 & & & & & & & & & \\
\hline $\begin{array}{l}\text { Testudi- } \\
\text { nata }\end{array}$ & $\begin{array}{l}\text { Trachemys } \\
\text { scripta elegans }\end{array}$ & 6 & & 19 & & & & 11 & & & & & & & 2 & & 7 \\
\hline \multirow[t]{6}{*}{$\begin{array}{l}\text { Squa- } \\
\text { mata }\end{array}$} & $\begin{array}{l}\text { Takydromus } \\
\text { amurensis }\end{array}$ & 1 & & 1 & & & & & & & & & & & & & \\
\hline & $\begin{array}{l}\text { Elaphe } \\
\text { rufodorsata }\end{array}$ & 4 & 4 & 2 & & 1 & & & & & & 4 & 7 & 2 & 3 & 1 & 3 \\
\hline & Elaphe dione & 2 & & & 1 & & & 1 & & & 1 & 1 & & & & & 5 \\
\hline & $\begin{array}{l}\text { Rhabdophis } \\
\text { tigrinus tigrinus }\end{array}$ & 4 & 1 & 3 & 3 & & & & & & & & & 3 & 1 & 2 & \\
\hline & $\begin{array}{l}\text { Dinodon } \\
\text { rufozonatum } \\
\text { rufozonatum }\end{array}$ & 2 & & & & & & & & & & & & & & & \\
\hline & $\begin{array}{l}\text { Gloydius } \\
\text { brevicaudus }\end{array}$ & & 1 & 2 & & & & & & & & & & & & & \\
\hline Total & 19 & 13 & 11 & 11 & 5 & 5 & 5 & 8 & 2 & 2 & 5 & 6 & 2 & 7 & 8 & 8 & 7 \\
\hline
\end{tabular}

Numbers within a bracket indicate the number of a pair of egg sacs or egg masses. 
a
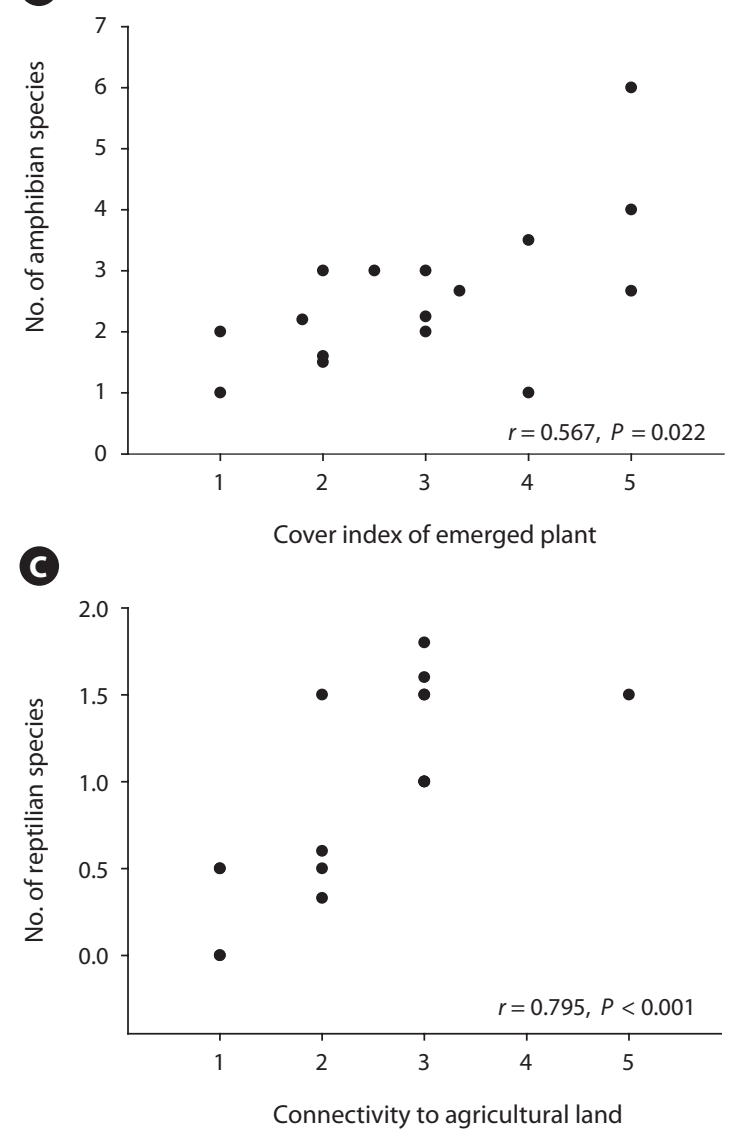

b

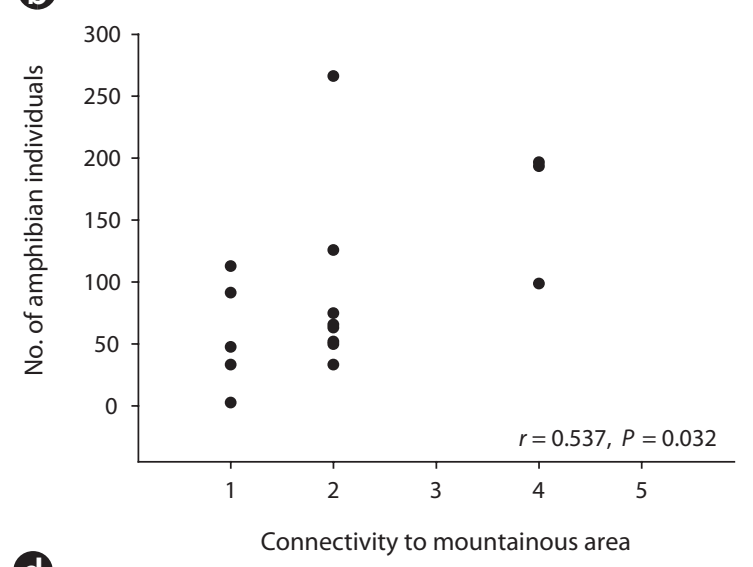

d

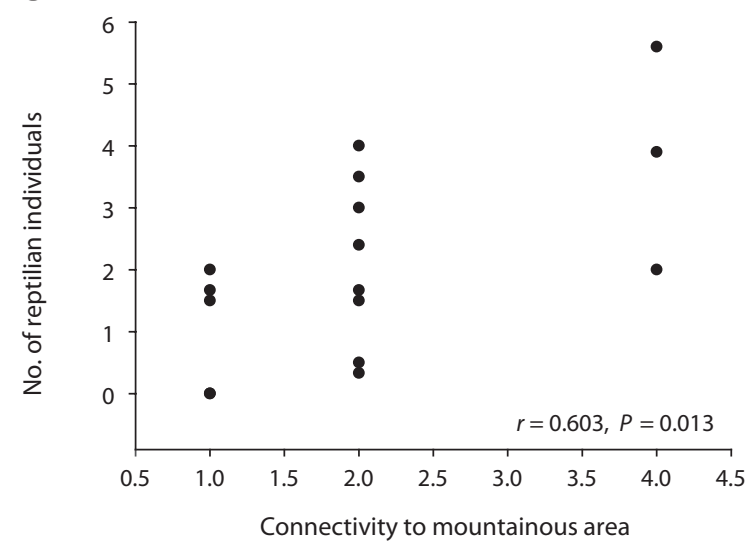

Fig. 2. Relationships between the number of amphibian and reptilian species $(a, c)$ and the number of individuals $(b, d)$ of them and their habitat characteristics.

$=0.032$ ) (Fig. 2b) and negatively correlated with the $\mathrm{pH}(r$ $=-0.638, P=0.008)$ and the distance to the nearest mountain $(r=-0.615, P=0.011)$.

The number of reptilian species was positively correlated with connectivity to agricultural land $(r=0.795, P$ $<0.001$ ) (Fig. 2c) and mountainous area $(r=0.597, P=$ $0.015)$, as well as the lagoon perimeter length $(r=0.540$, $P=0.038)$. The number of reptilian individuals was correlated positively with the number of birds $(r=0.518, P=$ $0.040)$, connectivity to mountainous area $(r=0.603, P=$ 0.013 ) (Fig. $2 \mathrm{~d}$ ), lagoon size $(r=0.513, P=0.042)$, and lagoon perimeter length $(r=0.530, P=0.042)$, but was negatively correlated with the distance to the nearest road $(r$ $=-0.561, P=0.024)$.

Other factors, including DO, number of insect orders, and distance to the nearest residential area were not correlated with either the number of amphibian and reptilian species, or the number of individuals of them $(P>0.05)$.

\section{DISCUSSION}

We documented 11 amphibian and 8 reptilian species. The dominant amphibian was the black-spotted pond frog ( $R$. nigromaculata), and the dominant reptile was the red-eared turtle (T. scripta elegans), an invasive species. Connectivity to mountainous area affected the number of both amphibian and reptilian individuals. The salinity, $\mathrm{pH}$, and lagoon perimeter length also affected either the number of amphibian and reptilian species or the number of individuals of them. These results indicate that the eastern coastline lagoons host more amphibian and reptilian species than was previously surmised. In an effort to conserve the lagoon herpetofauna, nearby wetlands as well as connectivity to agricultural land and mountainous area should be protected, in addition to the lagoons themselves.

The studies thus far on Korean lagoon herpetofauna have been conducted for several lagoons. Seven of the amphibian species (Bombina orientalis, Bufo gargarizans, Hyla japonica, Rana dybowskii, Rana coreana, $R$. nigromaculata, Rana rugosa) and seven of the reptilian species we detected (C. reevesii, T. scripta elegans, Taky- 
dromus amurensis, E. rufodorsata, Elaphe dione, Rhabdophis tigrinus tigrinus, Gloydius brevicaudus) have been reported previously in Korean lagoons (Kim 1997, Shim 2001, Lee and Song 2002a, 2002b). Four amphibians (Hynobius leechii, Bufo stejnegeri, K. borealis, R. catesbeiana) and one reptile (Dinodon rufozonatum rufozonatum) were newly documented in Korean lagoons. We also detected two endangered species $(K$. borealis and C. reevesii) in Seonyudam and Hwajinpoho, respectively, thereby indicating that the lagoons and nearby wetlands could represent appropriate habitats for these species. Although the density of these regions was quite low, additional surveys and conservation actions are clearly warranted.

The majority of amphibians and reptiles detected in the lagoons are common species that abound in agricultural wetlands, waterways, and low-lying areas (Kang and Yoon 1975, Song 2007). $R$. nigromaculata, $R$. coreana, $R$. catesbeiana, T. scripta elegans, E. rufodorsata, and R. tigrinus tigrinus are commonly detected in the majority of agricultural areas in Korea (Kang and Yoon 1975, Yang et al. 2001, Song 2007). We detected R. nigromaculata in all lagoons and R. coreana in 12 of the lagoons, whereas $B$. orientalis, B. gargarizans, and B. stejnegeri occurred in only one or two lagoons. Inside the lagoons, we detected only $R$. catesbeiana, $R$. nigromaculata, and T. scripta elegans. Our results indicate that the lagoons are critically important for amphibians and reptiles that primarily inhabit lowland areas.

Invasive species not only compete with endemic species, but also disrupt local ecosystems by functioning as new predators and transmitters of disease (Invasive Species Specialist Group 2000, Lowe et al. 2000, Gurevitch and Padilla 2004). In South Korea, 16 species of animals and plants are currently designated as invasive species, including R. catesbeiana and T. scripta elegans (Ministry of Environment of Korea 2009). In this study, we detected R. catesbeiana in four lagoons and T. scripta elegans in five lagoons, thus suggesting that they currently occupy the lagoon ecosystems. R. catesbeiana was the second most abundant amphibian and T. scripta elegans was the most abundant reptilian species in the studied lagoons. R. catesbeiana was detected at especially high densities in Cheonjinho and Bongpoho. In Gwangpoho and Yeongrangho, we detected R. catesbeiana at relatively low densities in small wetlands and ditches surrounding the lagoons. More than five T. scripta elegans were detected in Hwajinpoho, Songjiho, Yeongrangho, and Gyeongpoho, and we found both juveniles (carapace length, $5-10 \mathrm{~cm}$ ) and adults in Songjiho, thereby suggesting that they are breeding in lagoons. The extended distribution of these invasive species implies that they may disrupt endemic lagoon ecosystems.

Although the route by which the invasive species were introduced to these lagoons is not completely understood, R. catesbeiana may have been introduced intentionally for frog farming and T. scripta elegans may have been released during religious rituals (Bang 2006). The four lagoons with $R$. catesbeiana are located adjacent to each other, thereby implying that the American bullfrog may be extending its range into new lagoons and nearby bodies of freshwater. Although the importation of the red-eared turtle is now banned, their reproduction is already occurring in the lagoons. Thus, more studies of red-eared turtle population density, life history, habitat use in lagoons, and potential impacts on the endemic lagoon ecosystem should be conducted in the near future. The Ministry of Environment of Korea has begun to plan measures for the control of invasive species in Korean ecosystems (Bang 2006), and some local governments are currently attempting to eradicate these species. Our study indicates that the conservation or restoration of the endemic lagoon ecosystem will require the implementation of control or eradication measures for invasive species.

The number of amphibian species and the number of individuals of them were affected by $\mathrm{pH}$, salinity, emerged plant cover, number of birds, distance to the mountain, connectivity to mountainous area, and lagoon size, whereas the number of reptilian species and individuals were primarily affected by connectivity to the agricultural and mountainous areas, lagoon size, and lagoon perimeter length. Emerged plant cover and connectivity to mountainous area could influence the number of amphibian species and/or individuals by providing potential hiding places and shelters (Raxworthy and Attuquayefio 2000, Martin and MaComb 2003). As the amphibians have a permeable skin (Stebbins and Cohen 1995), higher $\mathrm{pH}$, and salinity, this could negatively affect the number of amphibian species and/or individuals. It has been known that birds, as one of the principal predators of amphibians, frequently forage for amphibian eggs, tadpoles, and frogs (Cushing and Allan 2001 , Wells 2007). For example, more than $34 \%$ of the total food items of the egrets and herons were identified as amphibians (Jenni 1973, Smith 1997). Therefore, it seems likely that the number of birds in a region could influence the number of amphibian species. With increases in the lagoon size, the number of amphibian species per unit area decreased, thereby implying that the appropriate 
habitat area might not increase at the same rate as the total lagoon area. Connectivity to agricultural land and mountainous area was associated significantly with the number of reptilian species or individuals, as it was for the amphibians. Such results may be associated with the fact that the reptiles detected in this study, such as E. rufodorsata, E. dione, and R. tigrinus tigrinus, principally inhabit agricultural and low-mountain regions (Kang and Yoon 1975, Song 2007), where the majority of Korean lagoons are located. The lagoon perimeter length was correlated positively with the number of reptilian individuals, implying that a longer perimeter might increase the appropriate habitats for reptiles, as well as connectivity to terrestrial areas. Although the distance to the roads was correlated negatively with the number of reptilian individuals, our observations of reptile roadkills near Hwajinpoho and Yeongrangho show that the roadkills may affect reptilian populations in lagoon ecosystems, as is the case in National parks (Song and Oh 2006, Min et al. 2008).

Many recent studies have demonstrated that to conserve biological diversity in wetlands, wetland areas as well as peripheral terrestrial areas should be protected (Bulger et al. 2003, Ra et al. 2008). Terrestrial buffer areas could protect water resources against pollution due to human activities and maintain appropriate water temperatures (Lowrance et al. 1984, Semlitsch and Bodie 2003). Additionally, terrestrial buffer areas provide key habitats such as hibernacula and foraging sites (Raxworthy and Attuquayefio 2000, Fellers and Kleeman 2007). Our results suggest that to conserve the herpetofauna of Korean lagoons, the lagoons themselves as well as the surrounding wetlands, grasslands, and mountains should be protected.

\section{ACKNOWLEDGMENTS}

We thank Junho Eom and Hyeon-Woo Choi for their assistance with the study. This study was supported by the Wonju Regional Environmental Office.

\section{LITERATURE CITED}

Bang SW. 2006. Monitoring System Establishment and Control Plan for the Invasive Species. Ministry of Environment of Korea, Gwacheon, pp 4-5. (in Korean)

Bulger JB, Scott JN Jr, Seymour RB. 2003. Terrestrial activity and conservation of adult California red-legged frogs
Rana aurora draytonii in coastal forests and grasslands. Biol Conserv 110: 85-95.

Cushing CE, Allan JD. 2001. Stream: Their Ecology and Life. Academic Press, San Diego, CA, pp 305-313.

Daum map sky view. 2009. Daum map. http://local.daum. net/map. Accessed 6 July 2009.

Fellers GM, Kleeman PM. 2007. California red-legged frog (Rana draytonii) movement and habitat use: implications for conservation. J Herpetol 41: 276-286.

Gurevitch J, Padilla DK. 2004. Are invasive species a major cause of extinctions? Trends Ecol Evol 19: 470-474.

Heo WM. 2009. Detailed Survey and Control Plan for the Conservation and Recovery of Lagoon Ecosystem along the Eastern Coastline (II), Final Report. Wonju Regional Environmental Office, Wonju, pp 22-75, 695-720. (in Korean)

Heo WM, Kim BC, Jun MS. 1999. Evaluation of eutrophication of lagoons in the eastern coast of Korea. Korean J Limnol 32: 141-151.

Hwang SI, Yoon SO. 2008. Geomorphic characteristics of coastal lagoons and river basins, and sedimentary environment at river mouths along the middle east coast in the Korean peninsular. J Korean Geomorphol Assoc 15: 17-33.

Invasive Species Specialist Group. 2000. IUCN Guidelines for the Prevention of Biodiversity Loss Caused by Alien Invasive Species. Species Survival Commission (SSC) Invasive Species Specialist Group, Auckland.

Jenni DA. 1973. Regional variation in the food of nesting cattle egrets. Auk 90: 821-826.

Kang YS, Yoon IB. 1975. Illustrated Encyclopedia of Fauna \& Flora of Korea, Vol. 17: Amphibia-Reptilia. SamHwa Publisher, Seoul. (in Korean)

Kim HS. 1997. A Report of Study on Natural Ecosystem of the Eastern Coastline Lagoons. Wonju Regional Environmental Office, Wonju. (in Korean)

Kim JA, Cho KH, Lee HHM. 2001. Vegetation structure of the Kungae reclaimed wetland in a coastal lagoon of East Sea, Korea. Korean J Ecol 24: 27-34.

Kim JB. 2009. Taxonomic list and distribution of Korea amphibians. Korean J Herpetol 1: 1-13.

Kim JH. 2005. Easily Find Insects. JinSun Press, Seoul. (in Korean)

Lee HS, Song MJ. 2002a. Mammals, birds, amphibians and reptiles. In: 2001 National Inland Wetlands Natural Environment Survey: Maeho, Hyangho (Ministry of Environment of Korea, ed). Ministry of Environment of Korea, Gwacheon, pp 173-183, 351-360. (in Korean)

Lee HS, Song MJ. 2002b. Mammals, birds, amphibians and reptiles. In: 2001 National Inland Wetlands Natural En- 
vironment Survey: Songjiho, Ssangho (Ministry of Environment of Korea, ed). Ministry of Environment of Korea, Gwacheon, pp 175-187, 345-353. (in Korean)

Lowe S, Browne M, Boudjelas S, De Poorter M. 2000. 100 of the World's Worst Invasive Alien Species: A Selection from the Global Invasive Species Database. Invasive Species Specialist Group (ISSG) a specialist group of the Species Survival Commission (SSC) of the World Conservation Union (IUCN), Auckland, pp 1-12.

Lowrance R, Todd R, Fail J, Hendrickson O, Leonard R, Asmussen L. 1984. Riparian forests as nutrient filters in agricultural watersheds. BioScience 34: 374-377.

Martin KJ, McComb BC. 2003. Amphibian habitat associations at patch and landscape scales in the central Oregon Coast Range. JWildl Manage 67: 672-683.

Min JH, Han GS, Choe BS, Im SJ, Won HJ. 2008. The frequency and characteristic of roadkills in Odesan National Park. Proceedings of the Korean Society of Environment and Ecology Conference (1): 87-88.

Ministry of Environment of Korea. 2009. Law for the Protection of Wildlife Fauna and Flora: Enforcement Regulations. Separate Table 2. Ministry of Environment of Korea, Gwacheon. (in Korean)

Park D, Cheong S, Sung H. 2006. Morphological characterization and classification of anuran tadpoles in Korea. J Ecol Field Biol 29: 425-432.

Pough FH, Andrews RM, Cadle JE, Crump ML, Savitzky AH, Wells KD. 2004. Herpetology. $3^{\text {rd }}$ ed. Pearson Prentice Hall, Upper Saddle River, NJ, pp 574.

Ra NY, Sung HC, Cheong S, Lee JH, Eom J, Park D. 2008. Habitat use and home range of the endangered gold-spotted pond frog (Rana chosenica). Zool Sci 25: 894-903.

Raxworthy CJ, Attuquayefio DK. 2000. Herpetofaunal com- munities at Muni Lagoon in Ghana. Biodivers Conserv 9: 501-510.

Semlitsch RD, Bodie JR. 2003. Biological criteria for buffer zones around wetlands and riparian habitats for amphibians and reptiles. Conserv Biol 17: 1219-1228.

Shim JH. 2001. Higher animals (vertebrate). In: $2000 \mathrm{Na}$ tional Inland Wetlands Natural Environment Survey: Hwajinpoho (Ministry of Environment of Korea, ed). Ministry of Environment of Korea, Gwacheon, pp 81-95. (in Korean)

Smith JP. 1997. Nesting season food habits of 4 species of herons and egrets at Lake Okeechobee, Florida. Colon Waterbirds 20: 198-220.

Song JY. 2007. Current status and distribution of reptiles in the Republic of Korea. Korean J Environ Biol 25: 124-138.

Song JY, Oh HS. 2006. Current status of road-killed amphibian and reptile and conservation plands in Songgye Valley, Woraksan National Park. Kor J Env Eco 20: 400-406.

Stebbins RC, Cohen NW. 1995. A Natural History of Amphibians. Princeton University Press, Princeton, NJ, pp 239.

Um JH. 1998. A study on the water quality, characteristics of sediments and local changes of lagoon, Maiho in East Sea. J Geogr Environ Educ 6: 95-110.

Wells KD. 2007. The Ecology and Behavior of Amphibians. The University of Chicago Press, Chicago, IL, pp 672673, 682-689.

Yang SM. 2003. Ecological characteristics and its educational utilization of the lagoon ecosystem in the east coastal region, Korea. MS Thesis. University of Gangneung, Gangneung, Korea.

Yang SY, Kim JB, Min MS, Seo JH, Kang YJ. 2001. Monograph of Korean Amphibia. Academybook, Seoul. 